\title{
Whe ditratian
}

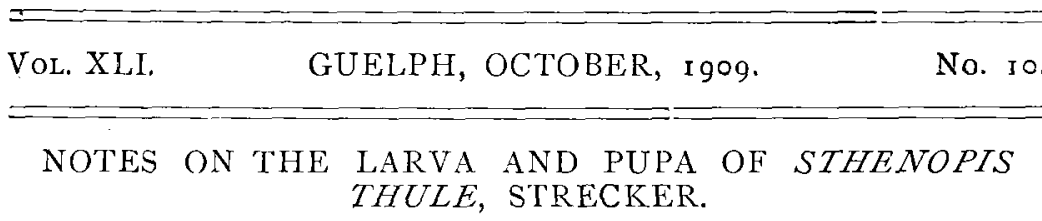

BY J. M. SWAINE, MACDONALD COLLEGE, P. $Q$.

Larvæ and pupæ of this interesting species were found in a willow swamp near Macdonald College by Mr. G. Chagnon, Mr. W. Brittain and myself on June 29 th, 1909 . They were taken from the bases of the stems of the common swamp willow, Salix petiolaris, Smith.

So far as we know, the mature larva and pupa have not been previously described.

Description of a neariy-mature larva: Length (alcoholic specimen), $70 \mathrm{~mm}$.; diameter at second abdominal segment, $9 \mathrm{~mm}$.; width of head, $5 \mathrm{~mm}$. The shape is nearly cylindrical, the thorax is slightly humped, and the last two abdominal segments are somewhat retracted ventrally. The colour is white or yellowish-white with yellow, chitinized thoracic areas and with small yellow-chitinized spots, from which arise the setæ. The setæ are sparse, dark brown, and longer and stouter on the last two abdominal segments. The body segments are much folded transversely, with a strong lateral fold on each side.

The spiracles are black, distinct, and situated on the first thoracic and first eight abdominal segments.

The abdominal feet are stout, situated on the third, fourth, fifth, sixth and last abdominal segments.

The head is reddish-brown, darker cephalad; with the labrum, mandibles and palpi black ; irregular furrows radiate from the sparse, setigerous punctures. The spinneret is slender, straight, and usually held at right angles to the body, though capable of being retracted flat against the ventral wall of the head. The ocelli are six in number, and are arranged in two more or less distinct rows.

The yellowish-brown cervical shield covers the dorsum of the first thoracic segment between the spiracles. Above the spiracles on either side is a slightly-curved, elongate, brownish-black, impressed marking, bearing a black setigerous puncture at either end and one cephalad of the middle. 


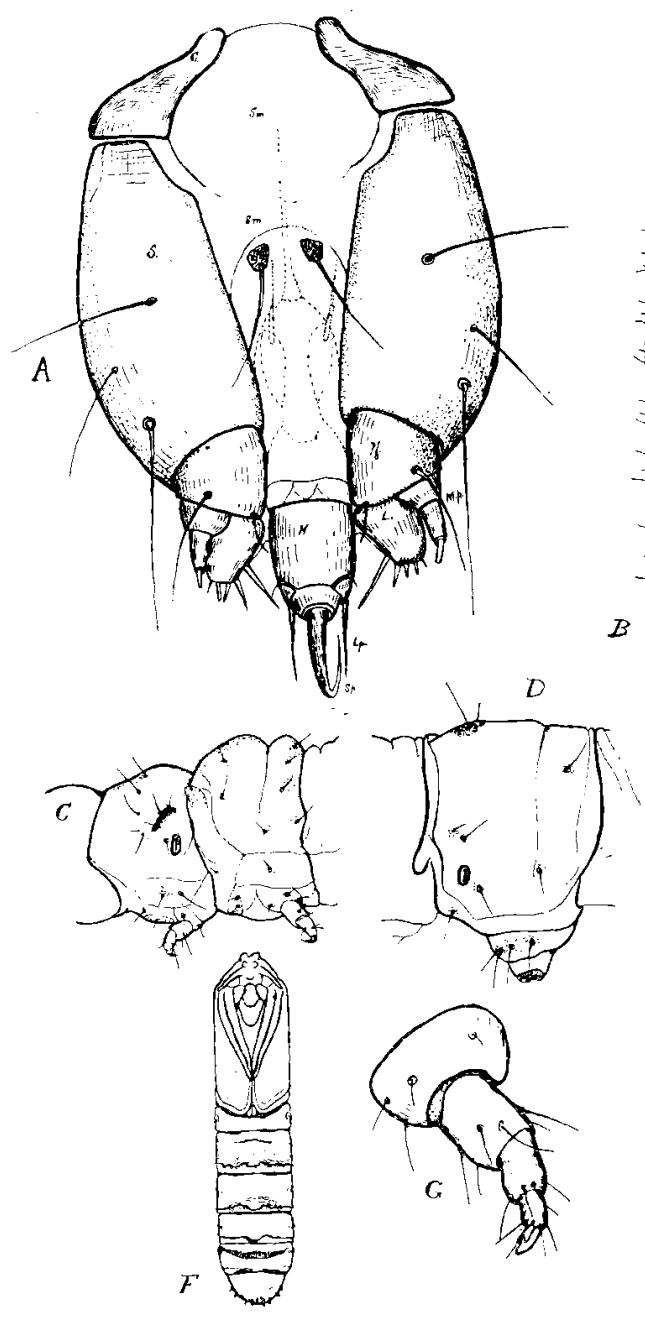

FIG. ro--Sthenopis thule.

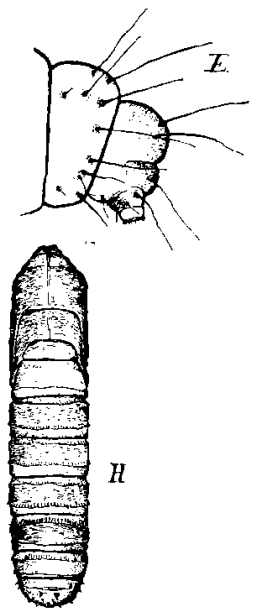

The anal plate is strongly chitinized, and bears stout, black setre, as shown in figs, $E$ and $K$.

The chitinized dorsal areas, arrangement of setæ, and other details, are shown in the accompanying figures.

The smallest larva differs from the above description in the relatively 
longer and blacker setæ, and in having the yellow, basal plates of the setæ replaced by relatively larger, well-defined, and very distinct blackish areas.

Ve have obtained, since the flight of the adults ended, larvæ with the following widths of heads: $2 \mathrm{~mm} ., 3 \frac{\mathrm{I}}{3} \mathrm{~mm} ., 3 \frac{3}{4} \mathrm{~mm} ., 4 \frac{1}{4} \mathrm{~mm}$, $43 / 4 \mathrm{~mm} ., 5 \mathrm{~mm}$. The length of the smallest specimen is $19 \mathrm{~mm}$., the diameter $2 \frac{\mathrm{I}}{4} \mathrm{~mm}$. These measurements are taken from alcoholic specimens.

We are breeding the larvæ in the greenhouse in the entire willow roots and in pieces of the roots, and hope eventually to be certain of the length of the larval life. At present, allowing for the varying size of puper

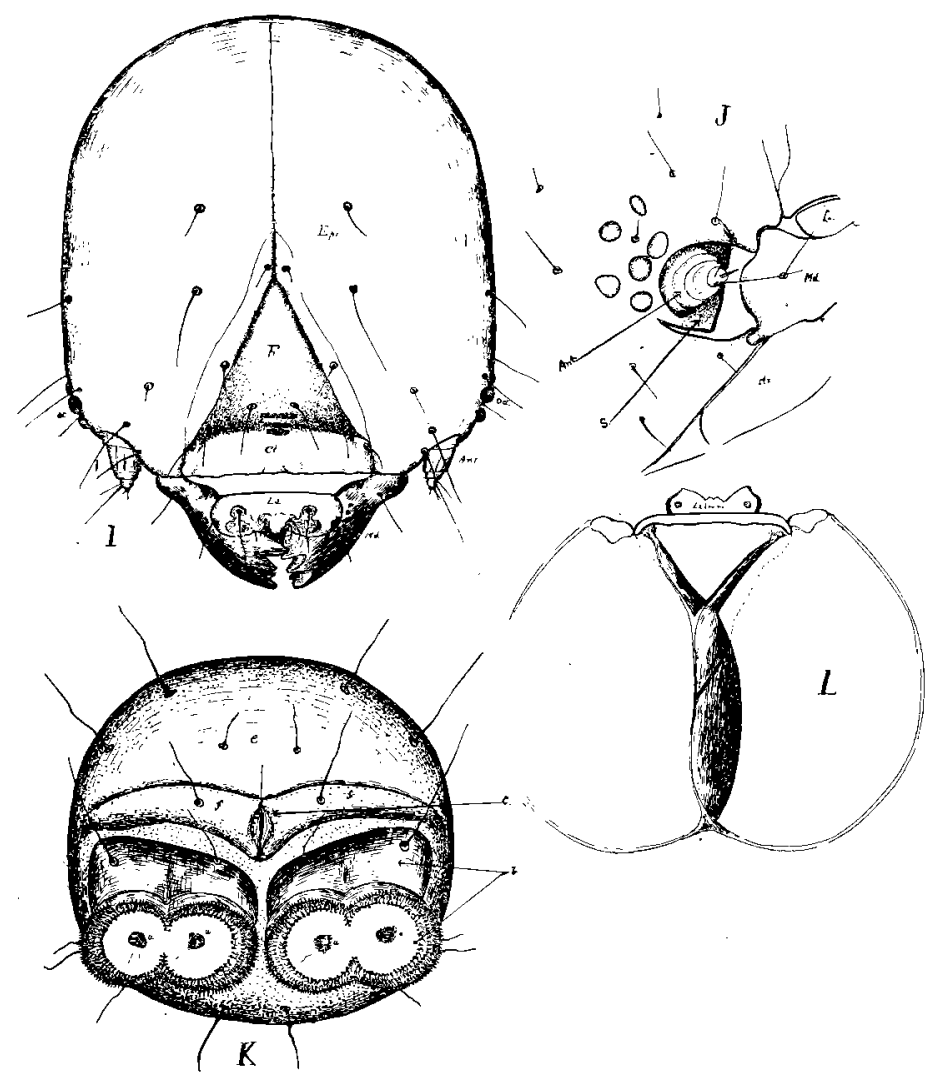

FlG. Ir.-Sthenopis thule. 
and adults, I suspect that the larval life will be found to extend over three years at least.

Habits of the Larva.--The early habits of the larræ have not yet been discovered. The smallest specimens obtained by us dropped from the roots or stems, and their location could not be determined. All the larger larvæ were within the tunnels in the base of a stem, or in the main stem mass. Each larva cuts a tunnel, seldom over six or eight inches in length, nearly cylindrical, and of a diameter slightly larger than that of the larva. The tunnels of all the larger larvæ have the exithole, which is usually below the surface of the ground, already cut a year or more before the maturity of the larva. The tunnels end abruptly inwards, and are sharply angled just within the exit-hole.

The food of the caterpillar seems to be obtained entirely by enlarging the tunnel; short side tunnels are sometimes present. The relatively small amount of food to be obtained in cutting such a tunnel would indicate a long larval life.

The burrow seems to be kept perfectly clean until near the time of pupation. Then the larva frequently forms within the mouth of the burrow, or in the loose soil just below the surface of the ground, a cylindrical cocoon of pieces of decayed bark and roots fastened with silk, of which latter it has a copious supply. All the cocoons found were open at the ends, not over three inches in length, and usually somewhat larger at one end than the other. Several pupæ have been found within the tunnels without any trace of a cocoon.

The larvæ are extremely active, and wriggle vigorously when disturbed, emitting a large amount of dark brown saliva. They even attempt to bite one's fingers when held, and although not very successful in the attempt, their intentions are very evident. When disturbed in their burrows they move backwards or forwards very rapidly. When allowed to wander at will over a black cloth a thread of silk is seen to be spun wherever the larva goes. The head is waved from side to side, and the silk attached to the cloth at the end of each motion, thus leaving the silk attached in a zigzag line. When left in a box with fresh roots and rubbish, the latter is soon interwoven with a web of silk, and the roots are readily fed upon, an evident attempt being made to construct a tunnel.

When kept in a tin box a larva would frequently produce a sharp rattling sound, such as could be produced by a quick succession of blows 
of its strongly-chitinized head against the tin. The sound invariably ceased when the box was touched, or even when one walked near it. Probably this species has the habit observed in the case of Hepialus sequoiolus (Williams, 1905, Ent. News, I6:284).

The larvæ were not noticed to mutilate each other when kept together, as those of H. sequoiolus are known to do (Williams, 1905, Ent. News, I6 : 20).

The larve and pupæ are to be found chiefly in the bases of healthy and dying stems, although the main mass of the stem will usually be found pierced by numbers of old tunnels. The larve apparently worked mainly in the younger tissue near the surface of the ground.

Several parasitized pupæ were obtained, but the ichneumons contained therein died in the pupal stage. No other parasites were found.

Description of the pupa: The length varies from 3 to $4 \mathrm{~cm}$, the width from 7 to $8 \mathrm{~mm}$; colour dark reddish-brown, with head and dorsum of pro- and mesothorax black. The shape is cylindrical; the wings, legs and antennæ adhere closely, the thorax and abdomen are equal in width, and the sides are almost exactly parallel. The head lapers to a rounded point ventrally; the abdomen is broadly rounded behind. A very few inconspicuous yellow hairs are scattered over the surface. The head is very strongly chitinized, black, with flexuous corrugations, and with four irregular prominences and a median sulcus dorsally. This sulcus gives off a branch on each side which runs cephalo-ventrad behind each anterior prominence. Along these lateral sulci the cuticle splits upon transformation.

The prothorax is very strongly chitinized, black, and strongly, longitudinally corrugated dorsally, with a distinct median carina, more strongly marked cephalad. This carina is a continuation of the line of the dorsal sulcus of the head, and is continued as a narrow smooth line across the meso- and metathorax. The cuticle splits along this line at transformation. The mesothorax and metathorax are also strongly chitinized and corrugated dorsally, more strongly on the sides of the disc. The corrugations are transverse on the middle of the disc and irregular on the sides. The colour becomes lighter behind. The wings extend less than one-half (I 7/39) the length of the pupa. The tips of the third pair of legs project caudad between the tips of the wings. The first six abdominal segments are transversely and finely corrugated, more strongly cephalad. The 
corrugations of the last two segments are faint and irregular. The spiracles are distinct at the sides of all the abdominal segments excepting the first.

The abdominal segments from the third to the seventh bear each two parallel and toothed carinæ across the dorsum. The anterior of these is situated at a short distance from the anterior margin of the segment, and begins (see $7^{\text {th) }}$ on each side immediately cephalad and slightly ventrad of the spiracle. The posterior carina is parallel with the first, on the fourth, fifth and sixth segments, and extends in an irregular line across the venter. It is bent strongly caudad and considerably raised on the midventral line. On the third and seventh segments the posterior carina is indistinct. The anterior carina of the seventh segment is continued across the venter, bent strongly caudad and strongly raised. The last segment is hemispherical, marked by several more or less distinct, concentric carinæ, scattered tubercles, and a slit-like protuberance at the tip. The armature just described is undoubtedly of great assistance to the remarkably active pupa in working its way from the burrow or from the cocoon previous to transformation. The pupal skins are usually found projecting amongst leaves and rubbish on the surface of the ground near the mouth of the burrow, which is usually at or slightly below the surface. Sometimes, however, the pupal skins are found within the mouth of the tunnel.

During transformation the cuticle splits along the $\mathrm{Y}$-shaped sulci on the dorsal surface of the head and along the line mentioned before as extending across the head and thorax. The split ends at the first abdominal segment. On the venter the cuticle usually splits on the middle line as far as the middle of the fourth abdominal segment. The somewhat triangular portion of the cuticle covering the antennæ, eyes and bases of the palpi is invariably broken off.

The length of the pupal period is at least twelve days. A pupa, apparently recently pupated, was obtained June 28 th, 1909 . The adult emerged twelve days later at $5 \mathrm{p} . \mathrm{m}$.

We frequently collect the adults in the early evening ( 6 to 8 p.m.) by picking them from the bases of the willow stems, where they rest, head upwards, about six inches from the ground. Very often a number of wings, usually perfect, will be found at the base of the clump of willows, with the body completely vanished. The pupal skin is usually nearby. The robbers were not discovered, but doubtless mice are responsible. 


\section{Explanation of Figures io and it.}

Fig. A.-Maxillæ and labium seen from behind: C, cardo; L, lobe of maxilla ; Lp, labial palpi; M, mentum; Mp, maxillary palpi ; Pf, palpifer; S, stipes; Sm, submentum ; Sp, spinneret, usually held straight.

Fig. B.-Dorsum of larva.

Fig. C.-Setæ of first and second thoracic segments.

Fig. D. - Setæ of sixth abdominal segment.

Fig. E.-Setæ of last two abdominal segments.

Fig. F.-Venter of pupa.

Fig. G.-Right mesothoracic leg.

Fig. H.-Dorsum of pupa.

Fig. I.-Head of larva from the front: Ant, antenna; $\mathrm{Cl}$, clypeus; Epi, epicranium ; F, front ; La, labrum ; Md, mandible ; Oc, ocelli.

Fig. J.--Ocelli, antennæ, etc., of larva: Ant, antennæ; La, labrum ; $\mathrm{Md}$, mandible; $\mathrm{Mx}$, maxilla; $\mathrm{S}$, indication of an antennal sclerite.

Fig. K.--Last abdominal segment of larva seen from behind : A, central hooks ; $\mathrm{B}$, anal prolegs ; $\mathrm{C}$, anus ; $\mathrm{E}$, anal plate ; $\mathrm{F}$, movable chitinized plates.

Fig. L.-Dorsal apodeme.

$$
\text { Plate io. }
$$

Fig. M.-Adult in natural position, reduced.

Fig. N.-Pupa and last larval skin in burrow.

Fig. O.-Larva.

Fig. P.-.-Tunnels in the main stem-mass.

\section{INTERNATIONAL CONGRESS OF ENTOMOLOGY.}

The following local committee for the Dominion of Canada has been formed to co-operate with the International Executive Committee in the preliminary work of arranging for the first meeting of the proposed Congress of Entomology :

Prof. C. J. S. Bethune, Editor of "The Canadian Entomologist," Ontario Agricultural College, Guelph, Chairman.

Tennyson D. Jarvis, President of the Entomological Society of Ontario, Lecturer in Entomology and Zoology, O. A. College, Guelph. 